\title{
Performance of Private Sponsors towards Sustainable Piped Water Supply in Rural Bangladesh
}

\author{
A. K. M. Kamruzzaman ${ }^{1}$, Ilias Said $^{1} \&$ Omar Osman ${ }^{2}$ \\ ${ }^{1}$ School of Housing, Building and Planning, Universiti Sains Malaysia, Penang, Malaysia \\ ${ }^{2}$ Universiti Sains Malaysia, Penang, Malaysia \\ Correspondence: A. K. M. Kamruzzaman, School of Housing, Building and Planning, Universiti Sains Malaysia, \\ Penang, Malaysia, 11800 Pulau Pinang, Malaysia. Tel: 60-103-891-492. E-mail: kmasud1991buet@yahoo.com
}

Received: September 21, 2013 Accepted: December 10, $2013 \quad$ Online Published: December 30, 2013

doi:10.5539/mas.v8n1p83

URL: http://dx.doi.org/10.5539/mas.v8n1p83

\begin{abstract}
This paper evaluated performance of private sponsor's in implementing piped water supply schemes through partnership approach in rural villages of Bangladesh. Structured questionnaire were administered and collected data by using an interview method from 21 scheme mangers. Collected data were analyzed using descriptive statistics. Time, cost and efficiency were used as evaluation criteria for both implementation and operation period. The study findings revealed widespread incompetence of sponsors in preparing project proposals. Time spent for construction shows 19\% (4 sponsors) complete earlier than planned/required completion period; and $29 \%$ (6 sponsors) within the stipulated time whereas, remaining 52\% (11 sponsors) with some delay. 5\% (1) sponsor started commercial operation with $100 \%$ connections whereas, $10 \%$ (2), $25 \%$ (5) and $15 \%$ (3) commissioned the scheme with $60 \%, 50 \%$ and $40 \%$ of their target connections. $35 \%$ ( 7 ) of the sponsors operated their schemes with profit. This planning and management approach may be suitable for implementing sustainable rural piped water supply schemes in countries with similar context like Bangladesh.
\end{abstract}

Keywords: business plan, public private partnership, rural piped water supply, sustainability

\section{Introduction}

In developed countries water service providers are serving in a number of institutional modes: either privately or publicly owned, operating at a local, regional or national level (Foxon et al., 2002). However, in Least Developed Countries (LDC) such as Bangladesh, providing rural water supply through private entities is relatively new. Recently the Government of Bangladesh started to set up rural piped water systems in rural villages. These systems sustainability depends on investment modality, innovative institutional management, and skill operation, and maintenance. Only a few pilot schemes have been implemented, mainly through government agencies with either government or donor funding. But to expand the rural piped water supply (RPWS) facility in a large number of villages is not possible for government due to lack of funding. But over the last decade, due to scarcity of public funds for infrastructure development, many countries welcomed private sector entities to enter into long-term contractual agreements as investors, builders, or operators of utility service projects (Grimsey \& Lewis, 2002). Private operators are involved in rural water supply in the form of delegated contracting through PPPs (Lockwood \& Smits, 2011). It is assumed that private entities can improve the management as they can invest capital to improve infrastructure, improve system performance, reduce water rates and more responsive to consumer needs (Cardenas, 2011). The scope of private sector participation in water supply services includes service management to Build, Operate and Transfer (BOT) (Tayler, 2007). Such Public Private Partnership (PPP) in rural water supply is a new concept in Bangladesh. A few rural piped water supply schemes are implemented through PPP, which creates an avenue for channeling private fund to produce public goods and commercial management to ensure sustainable water supply. Scaling up implementation of any model should only be done after prudent evaluation, to identify approaches which are socially acceptable, technically feasible, environmentally sound and financially viable for long term sustainability (Ibrahim, 2004). However, a few empirical evidence of private sector success in managing piped water supplies in rural areas challenging commercial prospects of RPWS (Kleemeier, 2010). So, for smooth running of RPWS requires new institutional, management, operation and maintenance model (Kamruzzaman et al., 2012).

The article evaluated the performance of sponsors (local NGO/Firm) as a provider of rural piped water supply in 
relation scheme development, cost control, target achievement towards sustainability.

\section{Background}

Bangladesh is the most densely populated country in the world where 117.4 million ( $72 \%$ total population) lives in the rural villages (BBS \& UNICEF, 2009). About 81 percent have access to an improve source of drinking water. An estimated 12.6 percent of the total populations are exposed to arsenic contaminated water. However, lack of appropriate water options is one of the main barriers to the supply of safe drinking water to the people who are exposed to the risk of drinking arsenic-contaminated water in Bangladesh (Hoque et al., 2004). Different types of non chemical based (Deep Tube Well, Dugwell, Pond Sand Filter, and Rain Water Harvesting) and chemical based filters were tried for supply of arsenic- safe water. However, considering densely populated settlement in rural villages, piped water supply systems developed based on deeper ground water source emerged as a safe and viable mitigation option for rural areas. Although at present piped water supply coverage of rural areas is not remarkable, only $1 \%$ of total rural population (WHO \& UNICEF, 2013), it is anticipated that a large number of rural population will use piped water supply in the coming days ( $\mathrm{GoB}, 2005)$. While most of the pilot schemes (102 nos.) were developed by government through its line agencies and operated by communities i.e. water and sanitation committees (DPHE \& JICA, 2008), only a limited number of schemes (27 nos.) are developed jointly and operated by private sponsors/operators (DPC, 2010; Kamruzzaman et al., 2012). Such models draw largely on the success of small scale private operators in mobilizing resources. It supports private sponsors' planning, implementation and management of rural piped water schemes with capital grants, to ensure access for poor households.

Bangladesh Water Supply Program Project (BWSPP) has piloted innovative service delivery models in rural piped water supply and innvolved private sponsors, which demonstrated significant sector advancement. The project demonstrated rural piped water supply schemes in PPP mode involving partnerships between community and local private sponsors, partial private financing and risk taking, and long term operations by local operators. A nascent small-scale private industry has emerged to support rural piped water supply systems. BWSPP has established 21 innovative PPP village piped water schemes, which serve about 106,000 people, demonstrating the successful development of innovative water services delivery models and arrangements (DPC, 2010). The project has also provided some valuable lessons which may be helpful for planning future rural water service delivery interventions.

\section{Scheme Development Process}

Scheme development follows four distinct steps: i) development, planning, and design; ii) implementation and construction; iii) commissioning and operation; and iv) hand-over. Sponsor plays an important role in all phases of the project. It selects scheme location, prepared feasibility study report to business plan activities started from scheme planning, design and scheme implementation with partial capital cost sharing. Then sponsor will operate the scheme until their recovery of capital cost with its profit. Table1 shows responsibility of sponsor starting to end-up of the project.

Table1. Shows the activities of sponsors in project life cycle

\begin{tabular}{lcl}
\hline Scheme phases & Sponsor's Activities \\
\hline Planning and design & - & Site selection \\
& - Pre-feasibility study \\
& - Project proposal- cum -business plan \\
& - Getting approval from project authority \\
\hline Implementation & - Grant agreement signing \\
& - Financing \\
\hline Commissioning, & Construct infrastructure \\
operation and handing & - Tater supply to the beneficiaries as per service agreement \\
over (After capital cost & - Day- to- day operation and maintenance \\
recovery of sponsors) & - Capacity building of community regarding technical and \\
& & management aspects \\
\hline
\end{tabular}




\subsection{Scheme Proposal Preparation}

Selected sponsors prepared the scheme proposal following three steps. These are, namely, Inception reports (Pre feasibility study report), Scheme proposal part-I (Feasibility study report) and Scheme proposal part-II (Project proposal-cum-business plan). Sponsors are entirely responsible for preparing all these reports, which they do by engaging qualified personnel. Among them project proposal-cum-business plan guide the sponsor from implementation to long term operation of the schemes. A brief description of project proposal is given below:

Scheme Proposal Part - II, includes a technical description of the water supply unit; detailed engineering design including cost estimate; construction program; a financial plan with $\mathrm{O} \& \mathrm{M}$ costs and tariff projections; environmental and social impact mitigation program; a scheme management plan and institutional arrangements. In addition to the above, it includes the number of households agreeing to take connections, a plan for serving poor and vulnerable households, customer agreements, upfront contributions, and a CBO formation and service agreement. Project Proposal Part- II is treated as a business plan for the sponsor and a guide to the long-term operation of the scheme. Financial aspects of the business plan cover cost analysis, investment plan for implementation and operation. Tariff assessment and setting, affordability were checked. Based on fixed assets schedule considered depreciation and prepared projected income statement, cash flow statement and net present value, internal rate of return, cost benefit analysis, breakeven analysis, and sensitivity analysis for assessing financial viability of schemes. The scheme management plan and other contractual obligations are presented in detail in the business plan. From scheme implementation to operation and maintenance, all things are clearly defined in the Project Proposal Part-II.

\subsection{Scheme Implementation}

After approval of the Scheme Proposal Part - II, BWSPP and the sponsor signs a construction agreement defining mainly the (i) rights and responsibilities of parties, (ii) completion time, (iii) construction and supervision requirements, (iv) approved scheme cost, (v) grant condition, and (vi) disbursement criteria. The scheme implementation is guided by the grant agreement, which sets forth the plans for long-term operation and maintenance also.

\subsection{Scheme Operation and Maintenance}

The sponsor (NGO/Firm) is the sole authority responsible for long-term operation and maintenance of the scheme. In the scheme implementation, the sponsor is also financial partner of the Government. The Government, through project BWSPP, provides $70 \%$ of the scheme's cost; and the sponsor and community manage the remaining $30 \%$. At the scheme level each sponsor sets up a Community Based Organization (CBO) and a scheme general management team, which includes a scheme manager and a pump operator. Scheme managers and pump operators are salaried employees who are employed by the sponsor. The sponsor must meet the operating expenses, such as the salary of the management team, electricity bill, and routine maintenance service charge or profit of the sponsor from collecting the water tariff from the beneficiary households.

\section{Methodology}

This study used the data, which was collected by Development Planners and Consultants and compiled in the project completion report of BWSPP (DPC, 2010). Data were collected through structured questionnaire using an interview method from the scheme mangers of 21 schemes constructed by BWSPP. Descriptive statistics were used for data analysis. Performance of sponsors was evaluated based on time taken for proposal preparation, scheme implementation, and efficiency in scheme cost control. In the operation phase time taken to achieve the targeted number of connections, revenue collection, and scheme profitability were taken as performance indicators.

\section{Major Findings and Discussions}

\subsection{Proposal Preparation Capacity}

Project management performance is usually measured in terms of time, cost, and quality of the project which is implemented. Study results showed that sponsors take abnormally long periods to complete their project proposals. The project proposal preparation, submission and approval process took minimum nine to maximum 22 months. The study findings revealed widespread incompetence of sponsors in preparing project proposals. It is may be due to unavailability of technically skilled personnel of sponsors or inadequate guidance from the monitoring authority, BWSPP.

\subsection{Scheme Construction}

Sponsors were found to be very active in scheme implementation. According to the project guidelines, sponsors 
have to complete their construction works within eight months. Sponsors completed construction within a minimum of seven months to a maximum of 19 months, with an average of nine months. 19\% (four sponsors) completed construction earlier than planned/required completion period; and $29 \%$ (6 sponsors) completed the work within the stipulated time. The remaining $52 \%$ (11 sponsors) completed construction with some delay.

\subsection{Scheme Cost Control}

Sponsors controlled their scheme costs vey effectively. Among the 21 schemes, $29 \%$ (6) were implemented at a cost below the estimated budget. On the other hand, $29 \%$ (6) completed the construction exactly within the approved budget. Only 5\% (1) of the sponsors exceeded the approved estimate. This excellent performance of cost control is due to Output Based Aid (OBA) disbursement of 70\% grant amount, which ensures keen financial monitoring from project authority. Moreover, the financial participation of the sponsors in scheme construction makes them very conscious about financial matters and likely to meticulously control the expenses, in order to reduce their financial burden.

\subsection{Connection Target Achievement}

Sponsors showed remarkable achievements in creating beneficiary house connections. Within a short period of commercial operation $5 \%$ (1) achieved $100 \%$ of the planned connections. $10 \%$ (2) of sponsors connected more than $60 \%$; $25 \%$ (5) managed more than $50 \%$ of their target number of connections; and, $15 \%$ (3) sponsors connected more than $40 \%$ of their target. The remaining sponsors are increasing their connections day-by-day. Whereas, the previous study reported that out of 120 rural piped water supply schemes $79(64 \%)$ schemes started its operation with less than 20 house connections in which $94 \%$ of the schemes were managed by community (DPHE \& JICA, 2008). This study results clearly favors sponsors management over community management for RPWS.

\subsection{Financial Features of the Schemes}

Financial viability of the scheme depends on the number of house connections and corresponding revenue collections. Data collected on monthly revenue and expenses for each scheme on the month of September2010 showed 35\% (7) of sponsors running their schemes at a profit (DPC, 2010). This is really an encouraging feature for this new water service delivery model in rural Bangladesh.

\section{Conclusions}

Sustainability of rural water supply is the over-arching issue in the water supply sector. Especially in developing countries a number of different approaches are being tried as means to this end. Application of PPP in the rural piped water supply is a recent one. Involvement of NGO in rural water supply in scheme planning, designing, implementing and long term operation and management is in the pilot phase in Bangladesh. Preliminary results showed sponsors are weak in preparing technical proposals but effective in scheme implementation. It is too early to comment on management capacity of the sponsors, as operation and management activities have not yet gone on for a long enough periods. But the initial achievement in reaching house connection targets and corresponding revenue earning is noteworthy. Capacity building of the sponsors and relevant stakeholders is recommended to further improvement of the performance of all concerned parties. Success story of PPP management model for rural piped water supply may emerge it as a potential social business model in rural areas of developing countries such as Bangladesh. Well planned research, therefore, is required for elaboration of knowledge in this infant sector.

\section{Acknowledgements}

The study is funded by USM Research University Grant No. 1001/PPBGN/845048 and Bangabandhu Fellowship on Science and ICT Project.

\section{References}

BBS \& UNICEF. (2009). Multi- indictor Cluster Survey. Dhaka: BBS,UNICEF.

Cardenas, S. Cortina de. (2011). Does private management lead to improvement of water services? Lessonlearnt from the experiences of Bolivia and Puerto Rico. (Ph.D. Dissertation), The University of Iowa, Iowa.

Development Planners and Consultants (DPC). (2010). Final Report for External Monitoring \& Evaluation of Implemented Schemes/Sub-Projects under Component 1, 2 and 3 of Bangladesh Water Supply Program Project (BWSPP). Dhaka, Bangladesh.

DPHE \& JICA. (2008). Evaluation of the Performance, Village Piped Water Supply System (120 Schemes). Dhaka: Department of Public Health Engineering (DPHE), JICA. 
Foxon, T. J., Mcilkenny, G., Gilmour, D., Oltean-Dumbrava, C., Souter, N., Ashley, R., ... Moir, J. (2002). Sustainability criteria for decision support in the UK water industry. Journal of Environmental Planning and Management, 45, 285-301. http://dx.doi.org/10.1080/09640560220116341

Government of Bangladesh (GoB). (2005). Sector Development Plan. Dhaka, Bangladesh: Ministry of Local Government, Rural Development \& Cooperatives.

Grimsey, D., \& Lewis, M. K. (2002). Evaluating the risks of public private partnerships for infrastructure projects. International Journal of Project Management, 20, 107-118.

Hoque, B. A., Hoque, M. M., Ahmed, T., Islam, S., Azad, A. K., Ali, N., ... Hossain, M. S. (2004). Demand-based water options for arsenic mitigation: an experience from rural Bangladesh. Public Health, 118(1), 70-77. http://dx.doi.org/10.1016/S0033-3506(03)00135-5

Ibrahim, A. K. M. (2004). Rural Piped Water Supply in Bangladesh: Myth or Reality 30th WEDC International Conference, 2004 Vientiane, Lao PDR. WEDC (pp. 570-573).

Kamruzzaman, A. K. M., Said, I., Osman, O., Hasmori, M. F., \& Hossain, M. E. (2012). Water Business- Public Private Partnership in Rural Bangladesh. 3rd International Conference on Business and Economic Research I(3rd ICBER 2012), March 12-13, 2012, Golden Flower Hotel, Bandung, Indonesia (pp. 1511-1516). Retrieved from http://www.internationalconference.com.my/proceeding/3rd_icber2012_proceeding/ 103_317_3rdICBER2012_Proceeding_PG1511_1516.pdf

Klemmeier, E. L. (2010). Private Operators and Rural Water Supplies,A Desk review of Experience. Water Papers. The World Bank.

Lockwood, H., \& Smits, S. (2011). Supporting Rural Water Supply: Moving towards a Service Delivery Approach. Rugby: Practical Action Publishing.

Tayler, W. K. (2007). Options for private sector involvement in rural water supply provision in Pakistan. Journal of International Development, 19, 829-839. http://dx.doi.org/10.1002/jid.1404

WHO \& UNICEF. (2013). Progress on Sanitation and Drinking-Water -2013 update Geneva: World Health Organization. Retrieved November 13, 2013, from http://apps.who.int/iris/bitstream/10665/81245/ 1/9789241505390_eng.pdf

\section{Copyrights}

Copyright for this article is retained by the author(s), with first publication rights granted to the journal.

This is an open-access article distributed under the terms and conditions of the Creative Commons Attribution license (http://creativecommons.org/licenses/by/3.0/). 